\title{
特集【論説】 紛争・訴訟問題からみたまちづくり手法の有效性と限界
}

\section{まちづくりの経済学}

Economics of Town Development

Hiroyuki SESHIMO : Senshu University

瀬下 博之*

\section{1.はじめに}

まちづくりが多くの関心を集めている。都市再 開発や中心市街地の活性化の問題に, 都市計画法 や景観法，さらには地方自治の問題も絡んで，ま ちづくりや開発にともなう紛争とそれに対する解 決のあり方が模索されている。その現状からは, 都市開発規制や建築規制が，豊かな都市開発の実 現という観点から見て有効に機能しているとはと ても言えない状況にあることが分かる。まちづく りをめぐる現行の規制にはどのような問題がある のだろうか。この問題を考えるにあたり, 本稿で は，個別の事例や規制の問題には深く立ち入らず, 現行の都市開発規制や建築規制にどのような視点 が欠けているか, という点について議論したい。 その上で，効率的で豊かなまちづくりを実現する ために筆者らが提案してきた手法を簡単に紹介し たい。

以下では，まず 2 節でまち全体が一つの企業に よって所有されて意思決定される場面を考える。 そこでは賃貸市場が完全競争的ならば，効率的で 豊かなまちづくりが達成されうることを説明する。 3 節では, 自治体がそのような企業と同様には機 能しない理由を考察し，日本の現行のまちづくり のための規制が本質的に大きな欠陥を有している ことを説明する。4 節では, 所有権を集約するこ との意義と限界を指摘する。5 節ではプット・オ
プションを用いたまちづくりの手法の有効性を説 明したい。

\section{2. まち全体が企業なら}

まず仮想的に，まち全体が一つの企業である状 況を考えよう。すなわち，企業がまち全体の所有 者である状況を考える。この状況の下では完全競 争的な賃貸市場を前提とすると効率的で豊かなま ちづくりが実現されうる。これは以下のように説 明することができる。

企業は住宅, 事務所, 店舗等を賃貸し, その賃 料からの収益を株主に分配する。所有者である企 業は，このときどのようにまちをつくろうとする だろうか。企業はまち全体のデザインを考え，ど こにどのような道路をつくり，何をどの程度の規 模で建設し，どのように利用をするか考える。具 体的なまちのデザインについては周辺の状況や環 境等, さまざまな要因によって当然に異なる。た だし，企業はその成果を株主に還元しなければな らないから，企業がこのことを考虑してまちをつ くることにはかわりがない。このとき企業が株主 の利益を最大にしょうとするならば，賃料収入全 体を高めるように，まち全体の「価值」を高める まちづくりをすることになる。

たとえば，マンションを何棟も建てる計画を 持っている場合に，企業は一番南の棟だけにしか 日光があたらないような開発をするとは思われな 
い。より高い賃料でマンションを賃貸しようとす れば, マンション全棟から得られる賃料を最大に するように開発をデザインするだろう。居住者が 日照時間に強い関心を示すならば, マンション賃 料に与える日照時間の影響が大きくなる。そのよ うな場合には, 企業はその地区のマンション全棟, 全室で日照時間が十分に大きくなるように全体の 建物の配置や構造を考えるはずである。

また，低層住宅地全体を高層化することが望ま しければ, 低層住宅地区全体を高層化する可能性 はあるが，近隣周辺に低層住宅を残したままで, 一棟だけ突出した超高層マンションを建設すると いうのも, 通常は考えにくい。超高層マンション を建てて周辺の住環境が悪化すれば，その低層住 宅の賃料が低下する。超高層マンションから高い 賃料が取れても, 低層住宅の賃料の低下がそれを 上回ってしまえば意味がない。仮に建設するにし ても, 周辺住宅地の価值をできる限り下げないよ うに, 日照やビル風, 景観等に最大限に配慮した 設計や建設がなされるだろう。渋滞の発生を抑え るような道路や駐車場の整備なども積極的に検討 されるはずである。

このように考えると, まち全体が企業によって 運営されれば, 企業が効率性を追求する結果とし て, 渋滞や公害の発生も抑制され, 住環境にも景 観にも優れたまちが創り出されるだろう。

この結果は, 企業は利益を追求する結果として 景観や環境を犠牲にしかねないという直観的な主 張と全く逆の結論である。ここでは, 景観や住環 境の価值が人々にとって重要であればあるほど, 企業が利益を追求する結果として, 景観や住環境 も十分に整備された開発が実現する。

この議論から明らかなように，まちづくりで問 題となるのは，その担い手が企業であるからでも， 大規模資本を有しているからでもない。まち全体 を変えるほどの大規模資本を有することも，その 企業が利益を徹底的に追求するという行動原理自
体も，それ自体はまちの住環境や景観を悪化させ る要因にはなりえない。

上記の説明は，一見，かなり特殊な状況のよう に思うかもしれないが, 大規模な郊外住宅地の開 発の事例などはこれらの状況にきわめて近い。不 動産開発業者は大規模な郊外住宅地を開発する際 には，同時にスーパーマーケットなどの商業施設 を誘致したり，場合によっては小中学校の建設な どを自治体に働きかけたりする。まち全体の価值 を高めるためのさまざまな工夫や配慮が取り込ま れ，それらが実現すればするほど，開発した住宅 地の価值が高まって不動産開発業者は大きな利益 を得ることができる。

しかし，上の仮想的なまちとしての企業の議論 と, このような大規模郊外住宅地の事例には明確 な違いがある。大規模郊外住宅地の事例では, 住 宅が販売されて所有者が分散してしまうからであ る。販売前までは開発業者が郊外住宅地全体の売 却価值をできるだけ高めようとするが，いったん 売却されるとそのような総合的なまちづくりの担 い手はいなくなる。住宅が販売されれば, それぞ れの購入者は, 自分の所有する住宅とその土地に ついて効率的な利用を追求する。しかし, そのよ うな個別の利益追求に基づく意思決定がまち全体 の価值を高めるとは限らない。このとき個々の所 有者は自分の不動産の価值を高めることを重視し， 他人の犠牲も厭わなくなるからである。他人の不 動産の価值が低下しても, 自分は何の損害も受け ない。経済学の用語を用いれば「外部不経済」の 問題が発生する。もはや全体としての価值の向上 は保証されない。

なお，企業によるまちづくりが効率的で豊かな ものとなるためには, 完全競争的な賃貸市場が存 在しているという前提が極めて重要である。競争 的な賃貸市場が不動産の利用価值を適切に反映し なければ, 開発主体は社会的に効率的で豊かな都 市開発を実施しようとはしなくなる。独占的な賃 
貸契約が結べるならば，日照にもビル風にも留意 しない劣悪な大規模開発をも安易に実施しかねな い。競争的な市場による評価が介在するという点 が，土地をすべて国有化して政府が管理すべきと する共産主義的な主張とは一線を画する点であり， 上記の説明が, これらの主張の論拠には決してつ ながらない理由となる。

また賃貸借市場が完全競争的であると言うこと は賃貸契約の下で効率的な利用が達成されるとい うことを暗黙裏に仮定している。この点が所有権 を集約して開発する際に重要な論点になるが，こ の点については 4 節であらためて議論しよう。

\section{3. 自治体によるまちづくり規制}

\section{1 政府や自治体による管理}

所有権が分散されている通常の状況を考えよう。 この状況で，前節における企業の役割を，政府， 特にそのまちの自治体に任せることはできないの だろうか。自治体には本来, その行政区域内の利 益を最優先に考えて行動する役割が期待されてい る。所有権が分散している状況で, 自治体がまち の居住者全体の利益や満足, 効用を高めようと行 動するならば, 道路や公共的な施設の建設だけで なく, さまざまな規制を用いて, まち全体の価值 を高めるように，まちづくりを誘導してゆくこと が期待されるはずである。Tiebout（1956）の「足 による投票」の議論は, 自治体が既存の住民の利 益を最大にするように地方公共財を供給するなら ば，人々の移動を通じて効率的な地方公共財の供 給が達成されることを指摘している1。開発規制や 建設規制なども地方公共財の一種と考えることが できるから，この議論に従えば，規制を含めた自 治体によるまちづくりは社会的に効率的になり, 豊かなまちづくりが実現するはずである。

しかし, 日本の自治体のまちづくり規制には過
度に開発を抑制している印象を受けるものも少な くない。開発されるべき地域の規制が緩和されず， 規制の緩い，本来は開発される必要のないような 地域が開発されている。郊外地域の開発が進み, 中心市街地が空洞化している現状はそのような自 治体規制の失敗の典型であろう。

このように自治体が規制緩和に消極的なのは, 瀬下（2010）で指摘したように，既存の建築物や 構築物に硬直性や固定性があり，その規模を即座 に適切な水準まで拡大できないことに原因がある。 まちの土地の生産性などが上昇しても, それらの 影響は地価にすぐに体化 (capitalize) されるのに 対して, 規制緩和が地価を上昇させる効果は極め て小さい。規制緩和にともなう外部不経済も内部 化するため, その利益をほぼ相殺してしまうから である。この時, 建築物や構築物をすぐに建て直 せない限り，規制緩和の利益をほとんど享受でき ず，むしろ規制緩和にともなう開発からの外部不 経済の被害だけが大きくなる恐れがある。このよ うな既存住民の利益を考慮すれば，自治体が期待 通りに既存の住民達の利益を最大にするように意 思決定していても, 容積率の引き上げなどの規制 緩和には消極的になってしまう。そのような場合, 自治体によるまちづくり規制は，むしろ効率的な 土地利用や都市開発を阻害してしまう方向にゆが むことになる。

言うまでもなく自治体が地域の特定の産業や企 業の既得権益を保護しようとすれば，問題は一層 深刻になる。効率性や住民全体の満足の追及より も，新規参入の抑制そのものが目的になってしま うからである。

\section{2 都市計画規制, 建築規制は何が問題か}

日本で自治体が既存住民の利益を最大化しょう としても効率的で豊かなまちづくりを進めること ができないのは，実は日本の現行のような都市計

1 詳しい議論は中川雅之（2008）等を参照 
画規制や建築規制は豊かなまちづくりという観点 から見るとその手法として，本質的に欠陥のある 規制だからである。

日本の都市計画規制や建築規制は, 容積率や高 さ，面積などについての上限規制を前提としてい る。自治体が制定する条例や規制も程度の違いは あっても上限規制という点では, 基本的には同じ である2。しかし，このような単純な上限規制は開 発や建築にともなう外部不経済を内部化する仕組 みもなければ，外部不経済にともなう損害を補償 する仕組みも持っていない。現行の規制は, 単に 容積率や建坪率, 高さなどの測定できる基準に対 して開発可能な最大值を土地の用途などに応じて 定めているに過ぎない。

コースの定理（Coase（1960））は，取引費用が 小さく権利関係が明確であれば，その権利者に損 害を補償することを通じて外部不経済が開発主体 の意思決定の中で内部化され, 効率的で豊かな開 発が実現されることを説明する。この議論から， 外部不経済をコントロールするために必要な手段 は，上限を設定して規制するのではなく，損害を 補償して外部不経済を内部化するプロセスにある ことが分かる。

これに対して日本の現行の都市計画規制も建築 規制も，このような損害を補償する仕組みも，外 部不経済を内部化するプロセスも包含していない。 開発主体は, 規制の範囲内であれば基本的に自由 に開発でき，開発にともなう外部不経済を考慮す る必要はない。それゆえ開発主体はその上限が引 き上げられれば引き上げられるほど多くの利益を 得られるようになるから，できる限り高い上限水 準まで規制を緩めることを要求する。他方で開発 によって損害を被る住民等は, この規制の枠組み の中で何の補償も受けられない。補償を受ける仕
組みそのものが規制の中に内在されていない。そ れゆえできる限り厳しい規制が望ましくなる。

現行のような上限規制では, 開発利益を追求し たい人々は常に規制緩和を要求し, 既存の生活を 脅かされたくない人は規制強化を主張する。達成 される結果はせいぜい両者の折東案にしかなりえ ない。しかし，そのような折東案に基づく規制で は, どちらの立場から見ても常に不十分な規制と なる。

こうして決まる上限規制では, 誰のために何の ために規制するのか, その目的自体も曖昧になっ てしまう。実際，さまざまな特例的な緩和措置を 備えた現在の都市計画規制や建築規制をみると, そもそも当初の規制水準が何のためにどのように 決まったのかという点に対してさえ多くの疑問を 禁じ得ない。その状況は, あたかも規制緩和の特 例を政治的に演出する目的のためだけに当初の規 制水準があるのではないかという印象さえ受ける。

都市開発にかかわるいずれの紛争もこの延長線 上にある。開発業者は, さまざまな開発規制の特 例等を用いて設計し, 大規模開発の正当性を主張 する。現行の開発規制は, 既存住民の権利を守る ためではなく，むしろ開発主体が賠償を行わなく てすむ規準を定めているという点で, 免罪符の役 割を果たすものとなっている。開発規制では対抗 できない住民は, 景観や, 日照, 住環境など新し い法的根拠を持ち出しては開発を抑制しょうとす る。現行の都市開発規制は, 開発主体と既存住民 の紛争を解決するどころか, むしろ両者の紛争を 誘発するような中途半端な規制にしかなっていな $w^{3}$ 。

\footnotetext{
2 景観規制などでは色や素材などにも規制が及ぶ場合があるが,これらも色彩の鮮明さや素材の自由度に対する制限であり， 規制の手法としては上限規制と本質的な違いはない。

3 八田（1997）や福井（2001）の議論も参照
} 


\section{4. 所有権を集約する意義とその限界}

\section{1 所有権を集約する意義}

あらためて，まち全体が企業である場合に，豊 かなまちづくりが実現されうる理由を考えよう。 開発主体が誰であれ，どのような所有権構造を有 していようとも, 高層ビルを建てればビル風や日 照時間の減少，景観の悪化など開発に伴うさまざ まな問題が発生する。しかし，まち全体が企業で あれば，それにともなうすべての損害を自らの問 題として捉え，その損害をできるだけ抑えて開発 利益を享受しょうとする。そのため, 周辺の日照 や景観の悪化などに最大限配慮した開発が実施さ れる結果となる。企業は，外部不経済にともなう 損害がすべて自らの資産価值へ影響するというた め, すべての外部不経済の問題を完全に内部化し てまちづくりの意思決定をするようになる。これ がまち全体が企業である場合に，効率的で豊かな まちづくりが実現する理由である。

五十嵐他（2009）は，日本の都市計画規制の問 題に対して, 不動産の「総有」という考え方を主 張している。この考え方は上述のまち全体が企業 である場合と同様に, 全ての土地が一つの意思決 定主体に委ねられることになる。総有が実現され れば,一つの意思決定主体がその地域全体の開発 を総合的にデザインする。そのため, 賃貸市場が 完全競争的であれば外部不経済を内部化するかた ちで都市開発が行われ, 効率的で豊かな開発が達 成されるだろう。五十嵐他（2009）は，このよう な総有の具体的な事例として, 香川県高松市の丸 亀商店街の再開発について説明している。この再 開発事例では, 開発会社が所有者達から土地を賃 借し, 建て直した商店街の建築物を, この開発会 社が所有し，権利床を所有者達に賃貸する。これ によって，意思決定は集約されることになる。

岩田（1997）は，都市開発ではないが，区分所 有マンションの建て替え問題を解決する手段とし
て, 証券化と定期借家権の組み合わせを提案して いる。証券化によって調達した資金で既存の区分 所有権をすべて買い取り，既存の区分所有者は定 期借家契約によって建て替え後のマンションに居 住する。この結果，すべての区分所有権が一つの 所有権に集約される。この手法は，区分所有建物 の建て替えだけでなく，より替模の大きな都市再 開発についても応用可能であるから，まちづくり や都市再開発でも同じ手法を用いることができる だろう。

\section{2 所有権を集約することの限界}

これらの手法は, 所有権を集約することを通じ て外部不経済を内部化することができるという点 で優れているが，問題もある。

まず，少なくとも既存の所有者全員がそのよう な枠組みに参加することに同意する必要がある。 賃借によって土地をまとめるにせよ，証券化を用 いて買い上げるにせよ既存所有者達の同意が成立 しなければスキームを利用できない。現在のよう に所有権が細分化し, 広範に分散化された状態を 前提とすると，それを集約するためにかかる交渉 費用や時間は決して小さくはない。Coase（1937） の議論が説明するように, 企業の規模はその取引 費用との関係で決まる。集約のための取引費用が 大きい場合には，まちづくりの観点から見て過小 な規模の集約しか進まない。この場合には効率的 で豊かなまちづくりは達成されない。

地方の商店街のような規模や比較的人口の少な い農村では，所有権を集約することはそれほど困 難ではないかもしれない。また, 証券化を用いた スキームはマンションや団地などの比較的同質な 不動産を前提とした場合にも適用可能かもしれな い。しかし，さまざまな利害の対立する主体が混 在する，空間的にもより広いまちの所有権を集約 することには, 多くの取引費用がかかることが予 想される。

さらに重要な問題は, 所有権を集約する結果, 
その利用を賃貸契約にゆだねることになるという 問題である。まち全体が企業である場合に，その まちづくりが効率的になるためには，完全競争的 な賃貸市場が存在する必要がある。すでに指摘し たようにこの前提において, 賃貸契約自体が持つ 問題が捨象されている。すなわち賃貸契約によっ て効率的な利用やメンテナンス投資が実現すると いうことが暗黙に仮定されている。しかし，賃貸 契約の場合, 賃借人の行動を所有者が正しく観察 することは事実上不可能で, そのような情報の非 対称性があると賃借人が不動産を過剩に利用した り，十分なメンテナンス投資を行わないなどのモ ラルハザードが生じかねない4。この点で賃貸契約 の形よりも利用権と処分権（売却権）を兼ね備え ている通常の所有権形態の方が不動産利用の観点 からは望ましい。なぜなら将来の売却価值を考慮 する結果, 適切な利用やメンテナンスが行えると いう利点があるからである。

賃貸契約が持つ問題点を考慮すると, 所有権を 集約することが必ずしも常に効率的な結果をもた らすとはいえなくなる。この場合には個別不動産 の所有権のままで開発主体に外部不経済を内部化 させることができるならば，所有権を集約するよ りも効率的なまちづくりが可能になる。所有権を 集約することは外部不経済を内部化するために有 効な手法の一つではあるが, 同時に現在の所有権 制度が有する機能や有効性を減殺する危険性をも 孕んでいる。そのため, 現在の所有権制度を前提 に外部不経済を内部化させる手法があるならば, その方法を追及することの意義は大きい。

\section{5. プット・オプションの利用}

既存の所有権制度を前提に, 外部不経済を内部 化させる方法として, 瀬下（2003）では「プット・
オプション履行義務付き開発許可制度」という都 市開発規制の手続きを提案した。この手続きは以 下のようなものである。まず容積率や高さ制限な どの上限規制はすべて廃止される。その代わりに, 周辺住民に対しては, その保有する不動産を再開 発前の市場価格で開発主体に売りつけることがで きるプット・オプションを与え, 開発主体にはそ の履行を義務づけるという開発許可制度を導入す るというものである5。また，周辺住民はプット． オプションを行使した後, その不動産をオプショ ン行使時の市場価格で買い戻すことも権利として 認められる。

開発にともなって外部不経済が発生すると, 周 辺の不動産の不動産価格にその損害が反映される ことを通じて, 不動産価格が低下する。プット・ オプションを行使することで，この值下がり分の 損失を被ることはない。買い戻す場合でも，行使 価格と買い戻し価格の差額分が手元に残るから実 質的に值下がり分が補償されることになる。この 結果, 開発にともなう外部不経済からの損失を開 発主体がすべて負担することになるから，開発主 体はそのような負担を考慮して開発を実施するこ とになる。すなわち, 外部不経済を内部化するこ とになる。

まちづくりにおいては，もちろん既存の不動産 をそのまま維持できず，その不動産自体が再開発 の対象になる場合もある。このような場合に対し ては, 山崎・瀬下 (2005) で,「プット・オプショ ン付き権利床転換手続き」という手法を提案して いる。これは以下のような手続きである。再開発 を進める開発事業者は従前の不動産保有者に, 不 動産と交換に再開発によって生み出される権利床 とこの権利床に対するプット・オプションが付与 される。開発主体がそのプット・オプションの履

この問題はRental externality などとも呼ばれる。例えばHenderson and Ioannides（1983）等の議論を参照。

5 詳しくは瀬下（2003）及び瀬下・山崎（2007）第 8 章参照 
行者となり, プット・オプションの権利行使価格 は従前の不動産の不動産価值に等しく設定される。 この手続きでは, 不動産保有者がプット・オプ ションを行使することによって従前の不動産価值 を保全できるだけでなく, 実は権利床に変換され た個別所有権の下で, 再開発地域の不動産保有者 の意思決定を集約する上でも機能する。これは, プット・オプションとその原資産である不動産を 保有することは，プット・オプションの権利行使 価格に等しい価值の安全資産と, プット・オプショ ンと同じ権利行使価格のコールオプションの合成 資産を持つことに等しいからである ${ }^{6}$ 。従って, 自 分の不動産価值を維持したままで都市再開発から の利益を享受できる立場になる。すくなくとも， 現在の不動産価值を維持できるから, この再開発 に反対する理由はなく, むしろ再開発からの利益 を最大化しようと試みるようになる7 既存住民は 開発利益を内部化できることで開発に協力するよ うになり，意思決定の集約が図りやすくなる。こ の点で所有権を集約することなく, 意思決定の集 約にかかる取引費用も軽減することが可能である。 再開発地域の周辺には上で説明したプットオプ ション付きの開発許可制度を適用すれば, 集約す る地域を開発地域に限定しながら, その開発がも たらす外部不経済を内部化することもできる。

このように再開発地域とその周辺の不動産所有 者にプット・オプションを与えることによって, 相対的に低い取引費用で開発に伴う外部不経済を 内部化し, 意思決定も集約でき, 社会的な観点か ら効率的で豊かなまちづくりが可能になると考え られる。

\section{6. おわりに}

本稿では，まち全体が一つの企業によって所有
されて開発される場合には, 賃貸契約に非効率性 が存在しない限りは, 効率的で豊かなまちづくり が可能になる。ここで重要なのは, 外部不経済が 内部化されるという点にある。現行の都市開発規 制や建築規制には，損害を被る人に対して補償す る手続はなく, 開発主体が外部不経済を内部化す ることに失敗している。所有権を集約することで も，外部不経済を内部化することができるが，こ のような手法は, 所有権の集約にかかる取引費用 が小さく，賃貸契約に非効率性が発生しないと言 うことを前提に正当化される。現在の細分化, 分 散化された所有権の状態を考えると，それを集約 するためにかかる取引費用は決して小さくはない。 また，賃貸契約に非効率性が存在する場合には, むしろ個別不動産の所有権を維持したままの方が 効率的な利用が促進されうる。これまで筆者らが 提案してきたプット・オプションを用いた開発許 可制度や都市再開発手法は, 既存の個別不動産の 権利を尊重した上で，相対的に低い取引費用で意 思決定の集約を図るとともに，外部不経済を内部 化できる手続きであると考えられる。

\section{Acknowledgement}

本稿は平成22年度科学研究費補助金 基盤研究 (B) 22330099による研究成果の一部である。

\section{参考文献}

Coase, R.H.,(1937) "The Nature of the Firm,"Economica, New Series, vol. 4, no. 16. 386-405.

Coase, R. H.,(1960) "The Problem of Social Cost,"Journal of Law and Economics, 3, 1-44

Henderson, J.V. and Y. M. Ioannides, (1983) "A model of Housing Tenure Choice" American Economic Review, 73(1), 98-113.

Hull, J.C. (2000) Option, Futures, \& Other Derivatives

\footnotetext{
${ }^{6}$ この関係はプット・コール・パリティーと呼ばれる。詳しくはHull （2000）などファイナンスやディバティブの教科書等 を参照

7 詳しくは山崎・瀬下（2005）及び瀬下・山崎（2007）第 9 章参照
} 
(Forth Edition), Prentice Hall Inc., Upper Saddle River, New Jersey.

Tiebout, C. M., (1956) "A Pure Theory of Local Expenditures," Journal of Political Economy, 64, 416-24.

五十嵐敬喜・野口和雄・荻原淳司 (2009)『都市計画法 改正一「土地総有」の提言一』第一法規.

岩田規久男 (1997)「マンションの法と経済分析」岩田 規久男・八田達夫『住宅の経済学』第 2 章 日本 経済新聞社.

瀬下博之 (2003)「マンション開発と住環境問題 : プッ ト・オプション履行義務付き開発許可制度の提 案」『都市住宅学』38号 58-64 都市住宅学会. 瀬下博之（2010）「自治体による開発抑制政策の経済 分析」『都市住宅学』70号17-23 都市住宅学会.
瀬下博之・山崎福寿（2007）『権利対立の方と経済学 所有権・賃借権・抵当権の効率性』東京大学出 版会.

中川雅之（2008）『公共経済学と都市政策』日本評論 社.

八田達夫（1997）「住宅市場と公共政策」岩田規久男· 八田達夫『住宅の経済学』第 1 章 日本経済新聞 社.

福井秀夫（2001）「権利の配分・裁量の統制とコース の定理」小早川光郎・宇賀克也編『行政法の発展 と変革 : 上巻』 有斐閣

山崎福寿・瀬下博之（2005）「市街地再開発の新手法 プット・オプションの導入」『応用地域学研究』 9 (2) 1-13 応用地域学会 